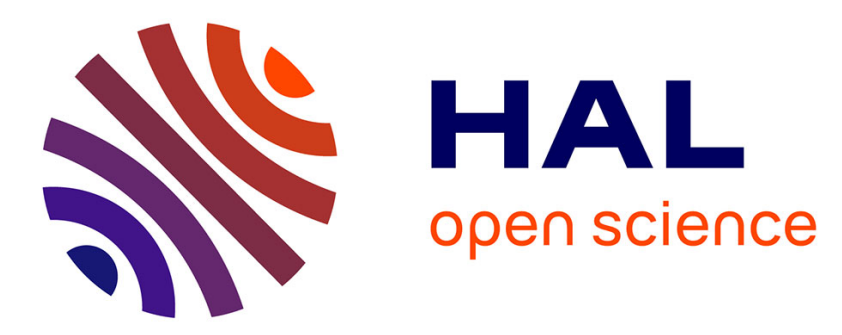

\title{
Metal nanoparticles in contemporary potters' master pieces: Lustre and red "pigeon blood" potteries as models to understand the ancient pottery
}

Philippe Sciau, Laure Noé, Ph. Colomban

\section{- To cite this version:}

Philippe Sciau, Laure Noé, Ph. Colomban. Metal nanoparticles in contemporary potters' master pieces: Lustre and red "pigeon blood" potteries as models to understand the ancient pottery. Ceramics International, 2016, 42 (14), pp.15349-15357. 10.1016/j.ceramint.2016.06.179 . hal-01339462

\section{HAL Id: hal-01339462 \\ https: / hal.sorbonne-universite.fr/hal-01339462}

Submitted on 29 Jun 2016

HAL is a multi-disciplinary open access archive for the deposit and dissemination of scientific research documents, whether they are published or not. The documents may come from teaching and research institutions in France or abroad, or from public or private research centers.
L'archive ouverte pluridisciplinaire HAL, est destinée au dépôt et à la diffusion de documents scientifiques de niveau recherche, publiés ou non, émanant des établissements d'enseignement et de recherche français ou étrangers, des laboratoires publics ou privés. 


\title{
ACCEPTED MANUSCRIPT
}

Metal nanoparticles in contemporary potters' master pieces: Lustre and red "pigeon blood" potteries as models to understand the ancient pottery

Ph. Sciau ${ }^{1}$, L. Noé ${ }^{1}$, Ph. Colomban ${ }^{2,3^{*}}$

${ }^{1}$ CEMES, CNRS, Université de Toulouse, 31055 Toulouse, France

${ }^{2}$ Sorbonne Universités, UPMC Univ Paris 06, UMR 8233, MONARIS, 75005, Paris, France

${ }^{3}$ CNRS, IP2CT, UMR 8233, MONARIS, 75005, Paris, France

*corresponding author. Tel : 3314427 2785; Fax: 3314427 3021.philippe.colomban@upmc.fr

\begin{abstract}
Reduction of metal precursors within the molten glaze is a rather complex route to obtain coloured glaze. "Sang de bœuf", "pigeon blood" or "flammé" first discovered glazes by the Chinese potters of the Song Dynasty $\left(10^{\text {th }} \mathrm{c}\right.$.) are produced by atmosphere controlled firing of copper-containing glaze on porcelain and stoneware body. Lustre pottery, an Abbasid potters' innovation $\left(9^{\text {th }}\right.$ c.), offers to the eyes of the connoisseur an iridescent reflection, which is only visible at specular position. For centuries connoisseurs' interest in these objects has been continuous and the development of transmission electronic microscopy (TEM) associated with energy-dispersive X-ray spectroscopy (TEM-EDX) allows us an in depth study of the micro and nano-structure of these objects. A porcelain with red "pigeon blood" decor made by the late famous French-American potter Fance Franck, and lustre stonewares made by the French potter Eva Haudum, have been investigated by TEM-EDX and nanochemical analysis in order to better understand the key parameters controlling the microstructure and the colour of glazes. Although some authors assigned the red colour of pigeon-blood to $\mathrm{Cu}_{2} \mathrm{O}$, our results clearly demonstrate that the colour only arises from $\mathrm{Cu}^{\circ}$ nanoparticles. Phase separation of the glassy phase was observed close to the surface. Concerning the lustrewares, analysis confirmed that the alternating reducing and oxidizing conditions during the firing lead well to the formation of metal-free/metal-rich alternate layers in the lustre decor.
\end{abstract}

Keywords: A : Firing ; C : Colour ; D : Porcelain ; metal nanoparticle 1. INTRODUCTION 


\section{ACCEPTED MANUSCRIPT}

The development of pottery is directly linked to the advancement of glaze technology - the glaze being the support of the coloured decor - and of the firing control, in particular of the oxidizing/reducing atmosphere. First Chinese glazes where prepared from plant ashes [1], a very fine powder well suited to prepare the slurry that is applied to the artefact, previously fired or not. Plant ashes still remain used by modern potters [2]. Alternatively, from B.C. epochs till to the ninth century A.D., in the Mediterranean area, instead of plant ashes, natron, an Egyptian natural deposit of sodarich salts, was used as flux of the mix. The elimination of iron and titanium impurities $[1,3]$ of the raw materials and the controlled addition of $3 \mathrm{~d}$ metal transition ions led to a variety of coloured glass and glaze $[3,4]$. Due to the low intensity of the colour, this technique is called 'couleurs transparentes' (optically clear colouration) and well adapted to colour 'thick' glass objects however poorly adapted to glaze that should be applied in rather thin layers $(<1 \mathrm{~mm})$. The incorporation of $3 \mathrm{~d}$ colouring ions in a specific matrix that promotes a high coloration power $[4,5]$ led to pigment that permits, even for a thin layer of glaze (hundred of $\mu \mathrm{m}$ ) a adequate colouration. Actually red colour cannot be easily obtained through this way. Nanosized (substituted) hematite experimented by Iznik potters [6], Meissen arcanists [7] and Japanese potters [8] led to dark red to orange shade. Rather similar colours were obtained by Roman potters, using hematite as colouring agents of the sigilatta slips [9]. Only nineteen the century innovations such as chrome-doped sphene pigments [10] giving pink to brown shade and $\mathrm{CdS}_{1-x} \mathrm{Se}_{\mathrm{x}}$-doped glasses giving a very vivid red colour $[5,11,12]$ offer efficient tools for red decors.

Another way of colouring the matter was the incorporation of metal nanoparticles, experimented a long time ago in Western Countries by Celts [13-15] and in Near-East countries by $19^{\text {th }}$ century Egyptian Dynasty [16] glassmakers. The huge light absorption of electronic interband and surface plasmon peaks makes allows for that a small amount of metal is sufficient to blacken thick glass piece (typically less than $0.5 \%$ in weight is sufficient to blacken $1 \mathrm{~mm}$ )! [15,17] The technique was largely used by Roman glassmakers [18] and then by medieval ones to colour stained glass in red (copper or more rarely gold-containing) or yellow (silver-containing) [19-21]. Addition of 


\section{ACCEPTED MANUSCRIPT}

multivalent elements such as $\mathrm{Sn}$ and $\mathrm{Sb}$ cause the development of crystalline phases that make the glass opaque and influence the colour. The technique spread as far as to China [22]. The technique gets a renewal at the end of the $19^{\text {th }}$ century $[23,24]$. Regarding the pottery glaze, the multivalent valence state of copper ions has been used in the Far East since the Northern Song Dynasty (Jun ware, $10^{\text {th }}$ century) to produce flame stoneware and porcelain [25-29]; i.e. the oxidizing flame giving turquoise $\left(\mathrm{Cu}^{2+}\right.$ ion) and the reducing one flammé ( $\mathrm{Cu}^{\circ}$ nanoparticle). No coloration is given by $\mathrm{Cu}^{+}$ ions [17]. Full red glazes, so called 'sang de boeuf or 'sang de pigeon' (ox/pigeon blood) were difficult to make and the first made artefacts, by the Chinese during the Ming dynasty (1368-1644), probably before the reign of Wanli (1573-1620) were collected by connoisseurs since early times. Examples of these older works are now rare. The process was at first difficult to control, but it had been mastered by the time of Kangxi (1661-1722) and Qianlong (1736-96) in the Qing dynasty, and a variety of red hue was developed (sacrificial red, chuihong, or "blown red", Langyao red, bright red, fresh red, peach-bloom red ... ) [26,30]. Among modern potters, the red porcelains of Fance Frank (1931-2008), a French-American potter who had been working at her Rue Bonaparte workshop in Paris since 1960s but also in New York (Greenwich House Pottery), Sèvres (Manufacture Nationale) and Arita (Fukagawa Factory)[31,32] are famous worldwide. Fig. 1a \& b shows examples of Fance Franck' masterpieces.

The story of lustre pottery is much older. Iridescent Roman glasses are mentioned in the Roret' Encyclopaedia [24] but to our knowledge no pieces have been discovered and hence analysed. Rare so-called lustered glass made by Copt and Fatimid glassmakers are identified [33,34], although these objects do not really exhibit iridescent reflects [35]. First lustre ceramic wares have been excavated from Baghdâd, Sâmarâ ou Suze but the most exceptional proof of the Abbasids' potters' expertise is the ensemble of lustre tiles of the Mihrâb installed in 862 in the Aghlabids Sidi Oqba Mosque of Kairouan (formerly Ifriqiya, now Tunisia) [15,36-39]. The technique then spread to Egypt, during the Tulunid Dynasty (868-905) who wanted to rival Baghdâd and Sâmarrâ. Early in the Fatimid period (909-1171), the objects were essentially decorated with beautiful animals or figural 


\section{ACCEPTED MANUSCRIPT}

decorations. Iran (Kashan), Anatolia then produced beautiful monochrome lustres and this technology was diffused throughout the Islamic world reaching Spain (Al Andalus) at the time of the Umayyad caliphs (929-1031). Under the Almoravid dynasty (1056-1147) but more likely under that of Almohad (1147-1269) lustre production in Murcia, Malaga, Siyasa, Paterna-Manises (Valencia) is grew and remained high during Nasride dynasty until the seventeenth century [15,37]. For instance the tiles of the famous Alhambra patio de los Arrayanes in Grenade were lustered. At the end of the fifteenth century, the technique spread, under the name of Majolica, to central Italy in centres such as Deruta, Gubbio and Caffaggiolo. At the end of the eighteenth century (J. Wedgwood in England) and in the second half of the nineteenth century, lustre technology attracted the interest of chemists-potters (for example Théodore Deck in France [23]): creations of Vilmus Zsolnay in Central Europe, William Morgan in England and Jean Clément Massier or Jean Mayodon in France [37]. The interest is still alive today, for example in France by Alain Dejardin, Eva Haudum or Jean-Paul Van Lith, in England by Sutton Taylor, Tony Laverick or Alan Caiger-Smith and in Spain by Joan Carrillo and Arturo Mora-Bonavent among others $[37,40]$. Fig. 2a shows an example of modern lustre stoneware made by Eva Haudum craftsman $[40,41]$.

"Best" ancient lustres consist of alternating layers with and without the dispersion of $\mathrm{Ag}^{\circ}$ or $\mathrm{Cu}^{\circ}$ nanoparticles close to the glaze surface $[15,42,43]$. Hispano-Moresque and Majolica potteries have also been largely studied but in many cases metal precipitates are only observed close to the surface $[44,45]$. A classification of the different types of lustre glazes has been proposed [15], from the high quality lustre made of quasi-ordered dispersion of metal particles in layers alternated with metal particle free ones to metalized glaze where the metal particles are only located close to the glaze surface. The procedure and mechanisms at the origin of the formation of the alternation of metal nanoparticle-rich and -free layers remains debated $[15,37,42-56]$. The availability of samples with controlled firing cycles led to the opportunity to go deeper into the understanding of the mechanisms involved in the lustre pottery preparation. 


\section{ACCEPTED MANUSCRIPT}

We report here the first comprehensive Transmission Electronic Microscopy study of copper containing "Sang de boeuf" glazed porcelain produced by Fance Franck [31,32] and lustre stonewares made by Eva Haudum [40]. The relative role of $\mathrm{Cu}^{\circ}$ metal particle and $\mathrm{Cu}_{2} \mathrm{O}$ crystals on the red colour has been questioned, some authors assigning the red colour to red $\mathrm{Cu}_{2} \mathrm{O}$ oxide [13,57-59]. The preparation route(s) of lustres, especially of polychrome ones (the decor is based on different coloured areas obtained by diffraction for the same angle of observation $[15,37])$ also remain(s) debated and hence the analysis of modern artefacts with controlled firing cycles offers an interesting comparison with previous TEM investigations on different monochrome and polychrome lustre pottery and will help to understand the complex phenomena involved.

\section{MATERIALS AND METHODS}

Fig.1 presents representative porcelain artefacts made by Fance Franck, for instance a 'pigeon blood' small bottle ( $10 \mathrm{~cm}$ high) and a cup ( $20 \mathrm{~cm}$ high) decorated with 'Sang de bœuf' birds (F. Franck - F. Delpiere Atelier Collection). The shape of the later object is inspired from antique votive Chinese cups [26]. The studied sample is a fragment of a bottle similar to that in Fig. 1a. A $\sim 10 \times 5 \times 2 \mathrm{~mm}^{3}$ piece is cut from the fragment using a Minitom Diamond saw (Struers, Danmark). Franck' objects are prepared on the potter' wheel using commercially-available hard-paste porcelain similar to the PDN paste developed at the Sèvres National Factory $[60,61]$. The glaze is prepared at the potter' workshop by mixing, and grinding together K-Na feldspar ( 50 wt\%), chalk (10.6 wt\%), flint ( $30 w t \%)$ in water. Small amounts of zinc ( 2 wt\%), kaolin (1 wt\%), talc (1.7 wt\%), tin oxide (3 $w t \%), \mathrm{MnO}(0.1 \mathrm{wt} \%)$, and $\mathrm{B}_{2} \mathrm{O}_{3}(1 \mathrm{wt} \%)$ are added in order to optimize the slurry behaviour and final glaze characteristics. Copper is added in the form of $\mathrm{CuO}(0.75 \mathrm{wt} \%)$. The final oxide composition, measured by electron microprobe (CAMECA SXFive microprobe) at the UMS 3623 Raimond Castaing of Toulouse, is given in Table 1. The glaze slurry is pulverized air on the green body. After air-drying the pieces are fired at $1335^{\circ} \mathrm{C}$ each of them in a SiC saggar using a natural gas heated kiln (mean 


\section{ACCEPTED MANUSCRIPT}

heating rate $\sim 90^{\circ} \mathrm{C} / \mathrm{h}$ ). The $\mathrm{CO} / \mathrm{CO}_{2}$ ratio is monitored by controlling gas input and exhaust: $\mathrm{CO}$ starts at $3 \%$ at $\sim 900^{\circ} \mathrm{C}$ and decreases up to $\sim 0.3 \%$ at $1335^{\circ} \mathrm{C}$ and similarly on cooling.

Fig. 2 a shows a lustre bowl made by Eva Haudum (diameter $\sim 11 \mathrm{~cm}$ ). The iridescence is clearly visible from a given angle of examination in the centre. Eva Haudum works with test pieces to develop her lustre decorations and she was kind enough to entrust us a few among the most representative of her creations. The investigations were carried out on sliced pieces from swan

pieces $\left(35 \times 4 \times 4 \mathrm{~mm}^{3}\right)$ and 3 of the examined samples are shown in Fig. $\mathbf{2 b}$. These objects were prepared on the potter' wheel using commercial stoneware pastes (coloured or white) and two types of commercial glazes: a glaze (sample 2 and 3 ) containing tin oxide and another one (sample 1) with less tin oxide but containing a small addition of zinc oxide, as revealed by electron microprobe analysis performed at the UMS 3623 Raimond Castaing of Toulouse (Table 2). After drying, the pieces are fired in a kiln heated with propane gas. The lustre preparation (clays and copper or silver salts) was applied with a pencil on the already glazed stoneware. Then the pottery was fired again at $\sim 600^{\circ} \mathrm{C}$, and the $\mathrm{CO} / \mathrm{CO}_{2}$ relative proportion was controlled. Change to oxidation condition leads to a fast increase of the temperature by about $100^{\circ} \mathrm{C}$.

The structure of decorative layers was studied by TEM on cross-section preparations. Imaging and EDX mapping were carried out using a Philips CM20-FEG electron microscope operating at 200 kV and equipped with a Microanalyse QUANTAX detector XFlash $30 \mathrm{~mm}^{2} 127 \mathrm{eV}$. Cross-sections of samples have been cut, glued together to form a sandwich, polished by mechanical grinding using SiC to a final thickness of 20-30 $\mu \mathrm{m}$, and then thinned by a precision ion polishing system (PIPS) with incidence angles of seven degrees operating at $5 \mathrm{kV}$ and $19 \mathrm{~mA}[54,56]$.

Micro-X-ray powder diffraction measurements were carried out on a Bruker D8 Advance device in Bragg-Brentano geometry, equipped with $15 \mathrm{~cm}$ long and $100 \mu \mathrm{m}$ in diameter optical fibber and a fast LynxEye detector. A Cu point focus anode was used to produce X-rays at the characteristic Cu fluorescence lines $\left(\lambda=C u K \alpha_{1,2}\right)$. Diffraction patterns were acquired between 10 and $80^{\circ} 2 \theta$ with a step size of $0.03^{\circ} 2 \theta$. 


\section{ACCEPTED MANUSCRIPT}

\section{RESULTS AND DISCUSSION}

\section{1. 'Pigeon blood' glazed porcelain}

Fig. 3 shows the comparison between the experimental $\mu$ XRD pattern recorded in the body close to the body-glaze interphase and the calculation with Maud software [62] for the two limit composition of mullite, $3 \mathrm{Al}_{2} \mathrm{O}_{3} 1 \mathrm{SiO}_{2}(3: 1)$ and $2 \mathrm{Al}_{2} \mathrm{O}_{3} 1 \mathrm{SiO}_{2}$ (2:1) [63-65]. The relative intensity of the two first Bragg peaks ( 16.3 and $26.22 \theta$ doublets, see on Fig. 3 the comparison with the calculated patterns of 2:1 and 3:2 compositions) clearly demonstrates the formation of 3:2 mullite. TEM investigation confirmed the type of mullite showing the dense mesh of acicular crystals with a section up to $~ 80 \times 80 \mu \mathrm{m}^{2}$. Lengths up to a few $\mathrm{mm}$ are observed (Fig. 4). The acicular crystals form a mesh structure that retains the molten amorphous potassium-rich aluminosilicate at the top firing temperature. Formation of a dense bird nest-like mesh of mullite needles is requested to keep the initial shape of the green body whatever the large amount of molten glassy phase that guaranties translucency of the porcelain body after cooling. Quartz phase detected in the diffraction pattern arises from the incomplete dissolution of some quartz grains, as commonly observed for hard paste porcelains $[3,60,65,66]$.

Fig. 5 compares the $\mu$ XRD patterns recorded at different spots along the ceramic section, close to the body-glaze interface. In the body (pattern a) and close to the body-glaze interphase (pattern b), a superimposition of the broad peak $\left(\sim 23^{\circ} 2 \theta\right)$ arising from the glassy phase and of the Bragg peaks of mullite and quartz crystals is obvious. As expected the broad feature centred at $23^{\circ} 2 \theta$ is observed for the glaze but careful examination of the 40 to $502 \theta$ range shows two supplementary small peaks characteristic of copper metal while no trace of copper oxides is detected (see Fig. 5 insert).

A TEM investigation from the body-glaze interphase to the glaze surface was carried out (Fig. 6). A contrast variation is observed close to the very surface as shown in Fig. 6a'; this indicates a 


\section{ACCEPTED MANUSCRIPT}

phase separation within the glassy phase, as observed for some Jun and "Hare's fur" or "Oil spot" glazes [67-69] and at the origin of the velvety aspect of these glazes. EDX measurements (Table 1) confirmed the presence of $\mathrm{Cu}$ but without being able to highlight a composition difference between the light and dark zones: copper ions are dissolved in the glass network. Further away from the surface, very small dark particles (around a few nanometres) are observed inside dark zones (Fig. 6b and $6 \mathrm{c}$ ), then the particles (Fig. $6 \mathrm{~d}$ and $6 \mathrm{e}$ ) are less numerous and larger (around $20 \mathrm{~nm}$ ) and finally rare copper crystals around one hundred nanometres are found close to the glaze-body interface

(Fig. $6 f$ and $6 \mathrm{~g}$ ). It can be assumed that these larger crystals are at the origin of the rather narrow small Bragg peaks observed in Fig. 5. However, the nanoparticles contain a high rate of $\mathrm{Cu}$ as attested by EDX, but no pattern was observed by electron diffraction according to the amorphous/disordered character of the small copper nanoparticles. At the glaze-body interphase small mullite crystals (Fig. 6a) were found as already reported. The above described complex nanostructure is at the origin of the very specific creamy aspect of 'pigeon blood' glaze.

\section{2. 'Lustre pottery}

Table 2 shows the complex composition of Eva Haudum' lustre glazes. The glaze thicknesses are around $500 \mu \mathrm{m}$ and the analyses were performed on cross-sections at around $100 \mu \mathrm{m}$ from the surface, under the nanoparticle layers. The complex composition is characteristic of modern glazes used by potters. Presence of boron oxide is expected and could be explained by the low total value. The glaze of sample 1 contains about 0.2 wt\% of equivalent $\mathrm{CuO}$, which is certainly at the origin of this deep red colour (copper Plasmon at $\sim 570 \mathrm{~nm}$, confirmed by UV-visible reflectometry) [15].

The metallic nanoparticles of the upper layers of the 3 samples were investigated using transmission electron microscopy. Representative TEM images are shown in Fig. $\mathbf{7}$ and $\mathbf{8}$ as well as in supporting information (Fig. S1, Supplementary content). EDX mapping revealed that the metallic nanoparticles of red sample (\#1) are exclusively copper while this is silver for the two other yellow 


\section{ACCEPTED MANUSCRIPT}

samples (samples 2 and 3). However all samples show an arrangement of metallic nanoparticles in multilayers.

The copper-based red sample 1 (Fig. 7) presents four rather well separated layers. The first layer (the closest to the surface) is constituted of the largest particles with an average size around to $50 \mathrm{~nm}$ (see the distribution size in Fig. S2, Supplementary content). The particles of the second layer are slightly smaller with an average size of around $40 \mathrm{~nm}$. The size distribution is also tighter. Layer 3 and 4 are formed of smaller particles with sizes ranging from 8 to $22 \mathrm{~nm}$. Layer 3 contains a few larger particles (around $40 \mathrm{~nm}$ ) as one can see in Fig. 7. Optical examination shows a large heterogeneity on the micron scale (Fig. S4), with a complex distribution of areas exhibiting a metallic shine within a red surface.

The nanoparticle layers of sample 2 (silver-containing glaze, Fig. 8) are thicker and the distribution sizes are somewhat less variable among the 3 layers. However the big particles are more numerous in the first layer, which also presents the largest size distribution. In fact it is made up of the two types of particle populations (Fig. 8 and S3, Supplementary content): very small silver particles with sizes ranging from 3 to about $15 \mathrm{~nm}$ and a population of larger particles with sizes ranging from 25 to $60 \mathrm{~nm}$. For the third sample this bimodal distribution of the top layer particles is even more pronounced (Fig. S3, Supplementary content). Details of the section of the above glaze close to the surface and the corresponding elemental mapping for two samples glazed are in Fig. S1 and Fig. S5. Sn elemental mapping shows clearly some big cassiterite $\left(\mathrm{SnO}_{2}\right)$ crystals $(\sim 0.5 \mu \mathrm{m}$ length) and a large distribution in size of silver metal nanoprecipitates. Bigger particles are also observed very close to the surface, according to Type 1 classification of ref [15]. No specific relationship is observed between the $\mathrm{SnO}_{2}$ particle distribution and the size/distribution of silver ones. Optical observation also shows a large heterogeneity (Fig. S4, Supplementary content).

The need of reducing/oxidizing sequences, as proposed before $[15,37,56]$ to form an alternation of metal particle-rich and -poor layers is clearly demonstrated. Low temperature (200$400^{\circ} \mathrm{C}$ ) ion-exchange between a solid open framework and a molten nitrate is well documented [70] 


\section{ACCEPTED MANUSCRIPT}

and as expected by many authors ion exchange led to the diffusion of silver/copper ions in the upper glaze layer. Metal particles should be formed under the action of reducing sequence. The lower diffusion coefficient of big molecular species such as $\mathrm{O}_{2}$ and $\mathrm{CO}$ and oxygen atoms in the covalent bonded glaze network with respect to that of small multivalence cations such as $\mathrm{Fe}^{\mathrm{n}}, \mathrm{Sn}^{\mathrm{n}+}$, etc. led to pointing out the significant role of redox reactions between copper/silver and multivalent cations $[15,37,54]$.

Coalescence or liquid separation between the molten glaze and the metal could explain the large size distribution of spherical metal particle at the glaze surface. Such complex multilayer structures have been observed in some shards excavated from Mesopotamia ( $9-10^{\text {th }}$ century), Fustat (Fatimids, $11-12^{\text {th }}$ century) and Termez (13-14 ${ }^{\text {th }}$ century), [54-56]. The layers without particles are not as thick and well defined as in a lusterware of the 12th Century from Fustat [55] but the particle organisation of these modern productions are very similar to the ones observed in other multilayers from Fustat and in some lusterware from Mesopotamia [54-56]. The main differences concern the $\mathrm{Ag}^{\circ}$ based lustres in which the silver nanoparticles often coalesced in ancient productions which is not the case in the two modern samples analysed.

\section{CONCLUSION}

Confirmation of the importance of the atmosphere control to obtain glaze coloured with metal nanoparticle is clearly confirmed. Alternation of oxidizing/reducing controlled sequence appears at the origin of the multilayer microstructure of the lustre decorations. More works on replica are needed to clarify the relationship between duration and/or temperature of the different sequences as well between phase separation in the glassy phase and metal particles growth. The present work shows how the medieval Chinese and Islamic potters, which were able to master the colour of a pottery have reached a perfect empirical knowledge of redox reaction in the glassy state.

\section{ACKNOWLEDGMENTS}




\section{ACCEPTED MANUSCRIPT}

Thanks to Eva Haudum for the gift of lustre stoneware samples and many discussions. M. J.

d'Albis and Mrs Yun de Collongue are kindly acknowledged for the permission to check the potter' archives of Fance Franck \& Francine Delpiere Atelier. The authors also would like to thank Sophie Gouy (UMS 3623 Raimond Castaing), Nicolas Ratel-Ramond (CEMES) and Catherine Crestou (CEMES) for technical support.

\section{References}

1. N. Wood, Chinese Glazes, Their Origins, Chemistry and Recreation, A\&C Black/University of Pennsylvania Penn Press, Philadelphia (1999).

2. Ph. Colomban, A. Tournié, Frère D. De Montmollin, Frère L. Krainhoefner, Vegetable ash as raw material in the production of glasses and enamels, for example the contemporary vegetable ashes from Burgundy, France, https://hal.archives-ouvertes.fr/hal-00542830/ (access 20th august 2015). Frère D. de Montmollin, The practice of stonware glazes; minerals, rocks, ashes, Editions de La Revue de la Céramique et du Verre, Vendin-le-Vieil (2005).

3. N. Q. Liem, G. Sagon, V. X. Quang, H. V. Tan, Ph. Colomban, Raman Study of the Microstructure, Composition and Processing of Ancient Vietnamese (Proto)porcelains and Celadons (13-16 ${ }^{\text {th }}$ centuries), J. Raman Spectr. 31 (2000) 933-942

4. Ph. Colomban, G. Sagon, X. Faurel, Differentiation of Antique Ceramics from the Raman Spectra of their Colored Glazes and Paintings, J. Raman Spectrosc. 32 (2001) 351-360.

5. R.A. Epler, D.R. Epler, Glazes and Glass Coatings, The American Ceramic Society, Westerville, 2000.

6. Ph. Colomban, V. Milande, L. Le Bihan, On-site Raman Analysis of Iznik pottery glazes and 


\section{ACCEPTED MANUSCRIPT}

pigments, J. Raman Spectrosc. 35 (2004) 527-535.

7. Ph. Colomban, V. Milande, On Site Analysis of the earliest known Meissen Porcelain and Stoneware, J. Raman Spectrosc. 37 (2006) 606-613.

8. F. Froment, A. Tournié, Ph. Colomban, Raman identification of natural red to yellow pigments ; ochre and iron-containing ores, J. Raman Spectrosc. 39 (2008) 560-568.560.

9. Ph. Sciau, S. Relaix, C. Roucau, Y. Kihn, D. Chabanne, Microstructural and Microchemical Characterization of Roman Period Terra Sigillate Slips from Archeological Sites in Southern France, J. Am. Ceram Soc. 89 (2006) 1053-1058.

10. X. Faurel, A. Vanderperre, Ph. Colomban, Pink Pigment optimisation by resonance Raman Spectroscopy, J. Raman Spectrosc. 34 (2003) 290-294.

11. L. C. Prinsloo, J.C.A. Boeyens, M.M. van der Rystb, G. Webb, Raman signatures of the modern pigments $(\mathrm{ZnCd}) \mathrm{S}_{1-\mathrm{S}} \mathrm{Se}_{\mathrm{x}}$ and glass matrix of a red bead from Magoro Hill, an archaeological site in Limpopo Province, South Africa recalibrate the settlement chronology, J. Mol. Struct. 1023 (2012) 1001-1113.

12. C. Fornacelli, Ph. Colomban, I. Memmi Turbanti, Raman/FORS characterization of CdSCdSe $(\mathrm{Zn})$ nanoparticles colouring red to yellow 20th century stained glass, J. Raman Spectrosc. DOI 10.1002/jrs.4758

13. N. Brun, L. Mazerolles, M. Pernot, Microstructure of opaque red glass containing copper, J. Mater. Sci. Letts 10[23] (1991) 1418-1420.

14. G. Artioli, I. Angelini and A. Polla, Crystals and phase transitions in protohistoric glasses, Phase Transitions 81 (2008) 233-252. 


\section{ACCEPTED MANUSCRIPT}

15. Ph. Colomban, The use of metal nanoparticles to produce yellow, red and iridescent colour, from Bronze Age to Present Times in Lustre pottery and glass : Solid state chemistry, spectroscopy and nanostructure, J. Nano Research 8 (2009) 109-132

16. Th. Rehren, E.B. Push and A. Herold, Glass coloring works within a copper-centered industrial complex in Late Bronze age Egypt, in: The Prehistory \& History of Glassmaking Technology edited, by P. Mc Cray, Ceramics and Civilization Series Vol. VIII, W.D. Kingery, Series Ed. The American Ceramic Society, Westerville (1998) 227-239.

17. Ph. Colomban, H. Schreiber, Raman Signature Modification Induced by Copper Nanoparticles in Silicate Glass, J. Raman Spectrosc. 36 (2005) 884-890.

18. P. Ricciardi, Ph. Colomban, A. Tournié, M. Macchiarola, N. Ayed, A non-invasive study of Roman Age mosaic glass tesserae by means of Raman spectroscopy, J. Archaeol. Sci. 36 (2009) 2551-2559.

19. Ph. Colomban, A. Tournié, P. Ricciardi, Raman spectroscopy of copper nanoparticlescontaining glass matrix: the ancient red stained-glass windows, J. Raman Spectrosc. 40 (2009) 1949-1955.

20. F. Farges, M.-P. Etcheverry, A. Scheidegger, D. Grolimund, Speciation and weathering of copper in "copper red ruby" medieval stained glasses from the Tours cathedral (XII-XIVth centuries), Appl.Geochem. 21 (2008) 1715-1731.

21. S. Pérez-Villar, J. Rubio, J.L. Oteo, Study of color and structural changes in silver painted medieval glasses, J. Non-Crystalline Solids Vol. 354 (2008) 1833-1844.

22. J. Zhu, H.P. Duan, Y.M. Yang, L. Guan, W. Xu, D.L. Chen, J. Zhang, L.H. Wang, Y.Y. Huang, C.S. Wang, Colouration mechanism of underglaze copper-red decoration porcelain (AD 13th14th century), China, J. Synchrotron Rad. 21 (2014) 751-755. 


\section{ACCEPTED MANUSCRIPT}

23. Th. Deck, La Faïence, Maison Quantin, Paris (1887).

24. H. Bertran, in Nouveau Manuel Complet de la Peinture sur Verre, sur Porcelaine et sur Email (Ed.: L. Mulo), Encyclopédie-Roret, Paris (1913)

25. Fukang Z. In Ancient Technology to Modern Science, Ceramics and Civilization, Vol. I, Kingery W.D. Ed., American Ceramic Society, Westerville (1984) 163-80.

26. W. Qingzheng, A Dictionary of Chinese Ceramics, edited by C. Kelun, J. Song, A. Lau, L. Minghua, N. Yibin, Z. Dong \& Z. Lili, Sun Tree Publishing Ltd-Oriental Art Publications,(2002).

27. M. Medley, The Chinese Potter - A practical history of Chinese Ceramics, Cornell University Press, Ithaca (1980).

28. Y.M. Yang, M. Feng, X. Ling, Z.Q. Mao, C.S. Wang, X.M. Sun, M. Guo, Microstructural analysis of the color-generating mechanism in $\mathrm{Ru}$ ware, modern copies and its differentiation with Jun ware, J. Archaol. Sci. 32 (2005) 301-310.

29. W.D. Kingery, P.B. Vandiver, Song Dynasty Jun (Chung) ware glazes, Am. Ceram. Bull. 62 (1983) 1269-1274.

30. I.C. Freestone, D.J. Barber, The Development of the Colour of Sacrificial Red Glaze with Special Reference to a Qing Dynasty Saucer Dish, in Chinese Copper Red Wares, R.E. Scott Ed. Percival david Foundation of Chines Art, Monograph Series $N^{\circ} 3$, University of London, School of Oriental and African Art, London, 1992, pp 53-62.

31. http://www.puckergallery.com/pdf/artist\%20bio/Fance\%20Franck.pdf (accessed $25^{\text {th }}$ February 2015) 


\section{ACCEPTED MANUSCRIPT}

32. Fance Franck, Study of Fresh Red Porcelain Glaze: a Potter's View, Percival David

Foundation of Chinese Art, Monograph Series, No 3, University of London (1991).

33. R.H. Brill in: Glass of the Sultans, S. Carboni and D. Whitehouse Eds, Yale University Press, New Haven (2000).

34. R. Ward (Ed.), Gilded and Enamelled Glass from the Middle East, British Museum Press, London, 1998.

35. P. Ricciardi, Ph. Colomban, A. Tournié, V. Milande, Non-destructive on-site identification of ancient glasses: genuine artefacts, embellished pieces or forgeries ?, J. Raman Spectrosc. 40 (2009) 604-617

36. G. Marçais, Les faïences à reflets métalliques de la grande mosquée de Kairouan, Geuthner, Paris (1928).

37. Ph. Colomban, Secrets retrouvés du Lustre abbasside, La Revue de la Céramique et du Verre, Novembre-Décembre, 139 (2004) 13-210.

38. O. Bobin, M. Schvoerer, C. Ney, M. Rammah, A. Daoulatli, B. Pannequin, R.P. Gayrau, Where did the lustre tiles of the SIDI OQBA mosque (AD 836-63) in Kairouan come from?, Archaeometry 45 (2003) 569-577.

39. O. Bobin, M. Schvoerer, C. Ney, C, B. Pannequin, E. Cilia Platamone, A. Daoulatli, R.P. Gayraud, The role of copper and silver in the colouration of metallic luster decorations (Tunisia, 9th Century; Mesopotamia, 10th Century; Sicily, 16th Century): A first approach, Color Res. \& Appl. Vol. 28 (2003) 352-359.

40. Reflets-Lustre Pottery, Gewerbe Museum - Winterthur Catalogue, Dialogue Céramique (C. A. Presset, A. Seiler, L. Umstätter \& D.Monod Editors), Genève, 2012 


\section{ACCEPTED MANUSCRIPT}

41. http://www.evaeva.fr/ (accessed 25th February 2015).

42. J. Perez-Arentegui, A Larrea, The secret of early nanomaterials is revealed, thanks to transmission electron microscopy, TrAC-Trends in Analytical Chemistry 22 (2003) 327329.

43. I. Borgia, B. Brunetti, I. Mariani, A. Sgamelotti, F. Cariati, P. Fermo, M. Mellini, C. Vitti, G. Padeletti, Heterogeneous distribution of metal nanocrystals in glazes of historical pottery, Appl. Surf. Sci.185 (2002) 206-216.

44. S. Padovani, C. Sada, P. Mazzoldi, B.G. Brunetti, I. Borgia, A. Sgamellotti, A. Giulivi, F. d'Acapito, G. Battaglin, Copper in glazes of Renaissance luster pottery: Nanoparticles, ions, and local environment, J. Appl. Phys. 93 (2003) 10058-10063.

45. G. Padeletti, P. Fermo, Production of gold and ruby-red lustres in Gubbio (Umbria, Italy) during the Renaissance period, Applied Physics A -Mater. Sci. Process. 79 (2004) 241245.

46. J. Roqué, T. Pradell, J. Molera, M. Vendrell-Saz, Evidence of nucleation and growth of metal $\mathrm{Cu}$ and $\mathrm{Ag}$ nanoparticles in lustre: AFM surface characterization, J. Non-Crystalline Sol. 351 (2005) 568-575.

47. J. Roqué, J. Molera, Ph. Sciau, E. Pantos, M. Vendrell-Saz,, Copper and silver nanocrystals in lustre lead glazes: Development and optical properties, J. Eur. Cer. Soc. 26 (2006) 3813-3824.

48. J. Roqué, J. Molera, G. Cepria, G, M. Vendrell-Saz, J. Perez-Arentegui, Analytical study of the behaviour of some ingredients used in lustre ceramic decorations following different recipes, Phase Transitions 81 (2008) 267-282. 


\section{ACCEPTED MANUSCRIPT}

49. E. Darque-Ceretti, D. Helary, A. Bouquillon, A, M. Aucouturier, G. Monge, Gold like lustre: nanometric surface treatment for decoration of glazed ceramics in ancient Islam, Moresque Spain and Renaissance Italy, Surf. Engn Vol. 21 (2005) 352-358.

50. S. Padovani, D. Puzzovio, C. Sada, P. Mazzoldi, I. Borgia, A. Sgamelotti, B.G. Brunetti, L. Cartechini, F. D’Acapito, C. Morizio, F. Shokoui, P. Oliali, J. Rahigi, M. Lamehi-Rachti, E. Pantos, Applied Physics A -Mater. Sci. Process. 83 (2006) 520-528.

51. P. Mazzoldi, C. Sada, A trip in the history and evolution of ion-exchange process, Materials Science \& Engineering B -Adv. Func. Sol. St. Mater. 149 (2008) 112-117.

52. T. Pradell, J. Molera, A.D. Smith and M.S. Tite : J. Archaeological Science Vol. 35 (2008) p1205.

53. A. Galli, M. Martini, E. Sibilia and G. Padeletti : Applied Physics A- Materials Science \& Processing Vol. 79 (2004) p293.

54. C. Mirguet, P. Fredrickx, Ph. Sciau and Ph. Colomban, Origin of the self-organisation of Cu degrees/Ag degrees nanoparticles in ancient lustre pottery. A TEM study, Phase Transitions 81 (2008) 253-266.

55. Ph. Sciau, C. Mirguet, C. Roucau, D. Chabanne, M. Schvoerer, Double Nanoparticle Layer in a 12(th) Century Lustreware Decoration: Accident or Technological Mastery?, J. Nano Research 8 (2009) 133-139.

56. Ph. Sciau, Nanoparticles in Ancient Materials: The Metallic Lustre Decorations of Medieval Ceramics, ch. 25, in Nanotechnology and Nanomaterials " "The Delivery of Nanoparticles", A. A. Hashim Ed., INTECH, http://www.intechopen.com/books/the- 


\section{ACCEPTED MANUSCRIPT}

delivery-of-nanoparticles/nanoparticles-in-ancient-materials-the-metallic-lustredecorations-of-medieval-ceramics (accessed 20th August 2015).

57. A.A. Ahmed, Ashour G.M., T.M. El-Shamy, Effect of melting conditions on the crystallization of coprous oxide and copper in glass, Proc. XIth INT; conf. GLASS 5prague), $2,1977,177-187$.

58. L. Dussubieux, B. gratuze, M. Belt-Lemarquand, Mineral soda alumina glass : occurrence and meaning, J. Archaeolog. Sci. 37, 201, 1646-1655.

59. P. Robertshaw, N. Benco, M. Wood, L. Dussubieux, E. Melchim, A. Ettahri, Chemical analysis of glass beads from medieval Al-Basra (Morocco), Archaeometry 52[3] 2010, 355-379.

60. Ph. Colomban, F. Treppoz, Identification and Differentiation of Ancient and Modern European Porcelains by Raman Macro- and Microspectroscopy, J. Raman Spectrosc. 32 (2001) 93-102.

61. A. d'Albis, Traité de la Porcelaine de Sèvres, Editions Faton, Dijon, 2003.

62. L. Lutterotti, "Total pattern fitting for the combined size-strain-stress-texture determination in thin film diffraction", Nuclear Inst. and Methods in Physics Research, B, $268,334-340,2010]$

63. Ph. Colomban, L. Mazerolles, $\mathrm{SiO}_{2}-\mathrm{Al}_{2} \mathrm{O}_{3}$ phase diagram and mullite non-stoichiometry of Sol-Gel prepared monoliths: influence on mechanical properties, J. Mater. Sci. Lett. 2 (1990) 1077-1079.

64. W.M. Carty, U. Senapatti, Porcelain - Raw materials, processing, phase evolution, and mechanical behavior, J. Am. Cer. Soc. 81 (1998) 3-20. 


\section{ACCEPTED MANUSCRIPT}

65. Y. Iqbal, W.E. Lee, Microstructural evolution in triaxial porcelain, J. Am. Cer. Soc. 83

(2000) 3121-3127.

66 N.Q. Liem, Ph. Colomban, G. Sagon, H.X. Tinh, T.B. Hoanh, Microstructure, Composition and Processing of the $15^{\text {th }}$ century Vietnamese Porcelains and Celadons, J. Cul. Herit. 4 (2003) 187-197.

67. Y.Q. Li, Y.M. Yang, J. Zhu, X.G. Zhang, S. Jiang, Z.X. Zhang, Z.Q. Yao, G. Solbrekken, Colourgenerating mechanism of copper-red porcelain from Changsha Kiln (AD 7th-10th century), China, Ceramics Int. 42 (2016) 8495-8500.

68. C. Dejoie, P. Sciau, W.D. Li, L. Noe, A. Mehta, K. Chen, H.J. Luo, M. Kuntz, N. Tamura, Z. Liu, Learning from the past: Rare epsilon-Fe2O3 in the ancient black-glazed Jian (Tenmoku) wares, Scientific Reports 4 (2014) 4941.

69. W.D. Li, H.J. Luo, J.N. Li, J.Z. Li, J.K. Guo, Studies on the microstructure of the black-glazed bowl sherds excavated from the Jian kiln site of ancient China, Ceramics Int. 34 (2008) 1473-1480.

70. Y.F. Yao and J.T. Kummer, lon exchange properties of and rates of ionic diffusion in beta alumina, J. Inorganic Nuclear Chemistry Vol. 29 (1967) 2453-2475.

Fig. 1: 'Pigeon blood' (a) and 'Sang de boeuf' (b) decorated porcelain artefacts made by Fance Franck (photo Ph. Colomban) 


\section{ACCEPTED MANUSCRIPT}

Fig. 2: a) Lustre pottery cup and b) studied test samples made by Eva Haudum (photo Ph. Colomban)

Fig. 3: Experimental XRD pattern recorded on the porcelain body (a \& c) compared to the calculated patterns ( $b$ \& d) for the Al-rich 2:1 (blue line, see online journal) and 3:2 mullite structures (red line, see online journal).

Fig. 4: Representative bright field TEM image of Fance Franck' 'pigeon blood' porcelain body and corresponding map of the $\mathrm{Al}$ and Si elements.

Fig. 5: MicroXRD patterns recorded on Fance Franck' 'pigeon blood' shard section (see insert micrograph) in three different spots: blue bottom spectrum, glaze top layer; middle red spectrum, middle of the glaze; black upper spectrum, porcelain substrate. Insert: detail of the 40 to 52 2] range highlighting the two copper metal Bragg peaks.

Fig. 6: Representative bright field TEM images of Fance Franck' 'pigeon blood' enamel recorded at different depths from the body to the glaze: a) mullite crystals observed close to the glaze/body interface, a' glaze phase separation at the very surface of the glaze; d) to g) images show representative microstructures, from top surface to glaze/body interface: clusters of Cu higher concentration are observed close to the surface then the evolution to the formation of larger Cu metal nanoparticles far to the surface.

Fig. 7: Representative bright field TEM images and corresponding elemental mapping of Eva Hudum' lustre sample 1 showing the layer organization and the increasing size of copper nanoparticles close to the glaze surface.

Fig. 8: Representative bright field TEM images and corresponding elemental mapping of E. Haudum' sample 2 showing the organization and the nature silver nanoparticles. 


\section{ACCEPTED MANUSCRIPT}

Table 1: Composition of Fance Franck 'pigeon blood' artefact.

\begin{tabular}{|c|c|c|c|c|c|c|c|c|c|c|c|}
\hline Material & $\mathrm{SiO}_{2}$ & $\mathbf{A l}_{2} \mathbf{O}_{3}$ & MgO & $\mathrm{Na}_{2} \mathrm{O}$ & $\mathrm{K}_{2} \mathrm{O}$ & $\mathrm{CaO}$ & $\mathrm{TiO}_{2}$ & $\mathrm{Fe}_{2} \mathrm{O}_{3}$ & $\mathrm{SnO}_{2}$ & $\mathrm{CuO}$ & Total \\
\hline Glaze & 73.1 & 10.1 & 1.1 & 1.1 & 4.3 & 6.9 & 0.01 & 1.1 & 0.16 & 0.28 & 98.3 \\
\hline Std Deviation & 0.9 & 0.2 & 0.1 & 0.1 & 0.1 & 0.5 & 0.02 & 0.2 & 0.06 & 0.13 & 0.6 \\
\hline Interphase & 64.1 & 22.9 & 0.1 & 1.7 & 5.7 & 2.9 & 0.01 & 0.4 & 0.04 & 0.12 & 97.9 \\
\hline Std Deviation & 4.5 & 5.9 & 0.1 & 0.2 & 0.7 & 0.7 & 0.01 & 0.1 & 0.02 & 0.05 & 0.6 \\
\hline Paste & 68.5 & 24.6 & 0.03 & 0.7 & 3.3 & 0.3 & 0.02 & 0.25 & 0.01 & 0.05 & 97.7 \\
\hline Std Deviation & 13.6 & 14.2 & 0.06 & 0.3 & 1.2 & 0.3 & 0.04 & 0.18 & 0.02 & 0.05 & 0.9 \\
\hline
\end{tabular}

Table 2: EDX composition of the Eva Haudum' lustre glaze

\begin{tabular}{|c|c|c|c|c|c|c|c|c|c|c|c|c|c|c|c|c|c|}
\hline $\begin{array}{l}\text { Sampl } \\
\text { es }\end{array}$ & $\begin{array}{l}\mathrm{Na}_{2} \\
\mathrm{O}\end{array}$ & $\begin{array}{l}\mathrm{Al}_{2} \\
\mathrm{O}_{3}\end{array}$ & $\begin{array}{l}\mathrm{SiO} \\
2\end{array}$ & $\mathrm{~K}_{2} \mathrm{O}$ & $\begin{array}{l}\mathrm{Ca} \\
\mathrm{O}\end{array}$ & $\begin{array}{l}\mathrm{Fe} \\
0\end{array}$ & $\begin{array}{l}\text { Mg } \\
0\end{array}$ & $\begin{array}{l}\mathbf{P}_{2} \mathbf{O} \\
5\end{array}$ & $\begin{array}{l}\mathrm{Cr}_{2} \mathrm{O} \\
3\end{array}$ & $\begin{array}{l}\mathrm{Zn} \\
0\end{array}$ & $\begin{array}{l}\mathrm{Ba} \\
0\end{array}$ & $\begin{array}{l}\mathrm{TiO} \\
2\end{array}$ & $\begin{array}{l}\mathrm{Cu} \\
\mathrm{O}\end{array}$ & $\begin{array}{l}\mathbf{A g}_{2} \\
0\end{array}$ & $\begin{array}{l}\mathrm{Sn} \\
\mathrm{O}_{2}\end{array}$ & $\begin{array}{l}\mathrm{Pb} \\
0\end{array}$ & $\begin{array}{l}\text { Tot } \\
\text { al }\end{array}$ \\
\hline Sampl & 2.4 & 10. & 62. & 4.33 & 2.1 & 1.3 & 0.2 & 0.0 & 0.00 & 5.4 & 1.0 & 0.1 & 0.2 & 0.0 & 0.5 & 0.0 & 90. \\
\hline $\begin{array}{l}\text { e } 1 \\
\text { Glaze }\end{array}$ & 6 & 55 & 11 & & 7 & 5 & 75 & 60 & 05 & 1 & 1 & 15 & 56 & 10 & 3 & 5 & 67 \\
\hline Std & 0.4 & 1.6 & 5.6 & 0.63 & 0.5 & 0.8 & 0.0 & 0.0 & 0.00 & 1.2 & 0.2 & 0.0 & 0.1 & 0.0 & 2.3 & 0.0 & 1.5 \\
\hline $\begin{array}{l}\text { Deviati } \\
\text { on }\end{array}$ & 1 & 7 & 0 & & 3 & 9 & 68 & 51 & 3 & 8 & 5 & 6 & 37 & 13 & 0 & 4 & 1 \\
\hline Sampl & 3.6 & 12. & 57. & 3.30 & 5.6 & 1.6 & 0.3 & 0.0 & 0.00 & 1.2 & 1.3 & 0.3 & 0.1 & 0.0 & 2.5 & 0.0 & 90. \\
\hline $\begin{array}{l}\text { e } 2 \\
\text { Glaze }\end{array}$ & 3 & 58 & 59 & 14 & 7 & 5 & 23 & 41 & 07 & 4 & 7 & 01 & 67 & 07 & 9 & 4 & 52 \\
\hline Std & 0.8 & 1.9 & 6.3 & 0.60 & 1.6 & 0.7 & 0.0 & 0.0 & 0.00 & 0.4 & 0.3 & 0.1 & 0.1 & 0.0 & 4.1 & 0.0 & 2.8 \\
\hline $\begin{array}{l}\text { Deviati } \\
\text { on }\end{array}$ & 5 & 1 & 1 & & 5 & 5 & 72 & 22 & 21 & 3 & 8 & 75 & 93 & 11 & 7 & 4 & 3 \\
\hline Sampl & 2.2 & 14. & 57. & 3.59 & 5.0 & 0.4 & 0.8 & 0.0 & 0.00 & 1.1 & 1.4 & 0.3 & 0.0 & 0.0 & 4.4 & 0.0 & 91. \\
\hline $\begin{array}{l}\text { e } 3 \\
\text { Glaze }\end{array}$ & 6 & 57 & 09 & & 4 & 8 & 6 & 4 & 09 & 7 & 4 & 9 & 18 & 07 & 4 & 4 & 42 \\
\hline Std & 0.3 & 1.8 & 5.0 & 0.48 & 1.1 & 0.0 & 0.1 & 0.0 & 0.00 & 0.2 & 0.2 & 0.1 & 0.0 & 0.0 & 6.8 & 0.0 & 1.6 \\
\hline $\begin{array}{l}\text { Deviati } \\
\text { on }\end{array}$ & 5 & 8 & 5 & & 7 & 6 & 6 & 17 & 3 & 6 & 5 & 4 & 22 & 11 & 7 & 3 & 5 \\
\hline
\end{tabular}




\section{ACCEPTED MANUSCRIPT}

a)

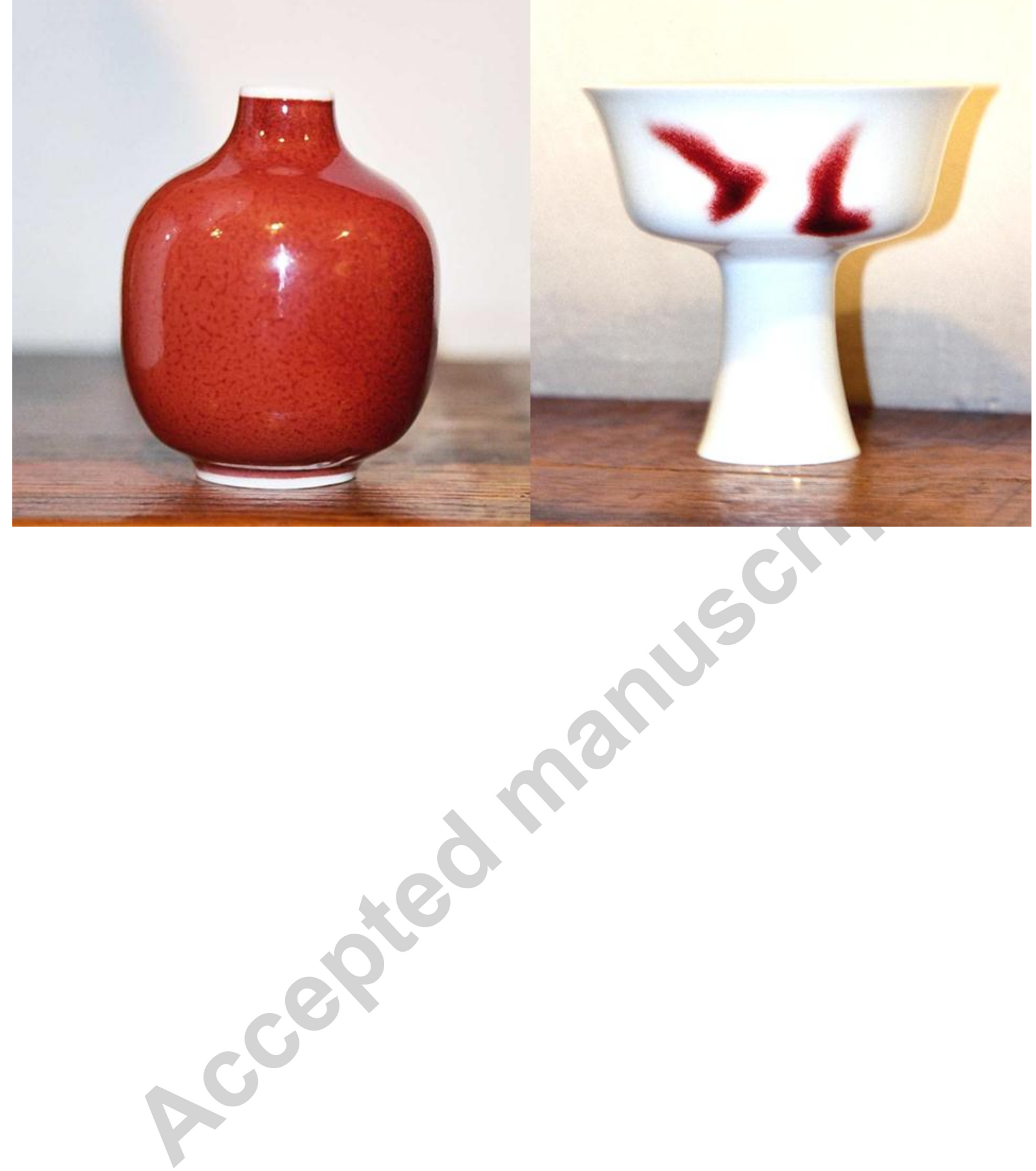




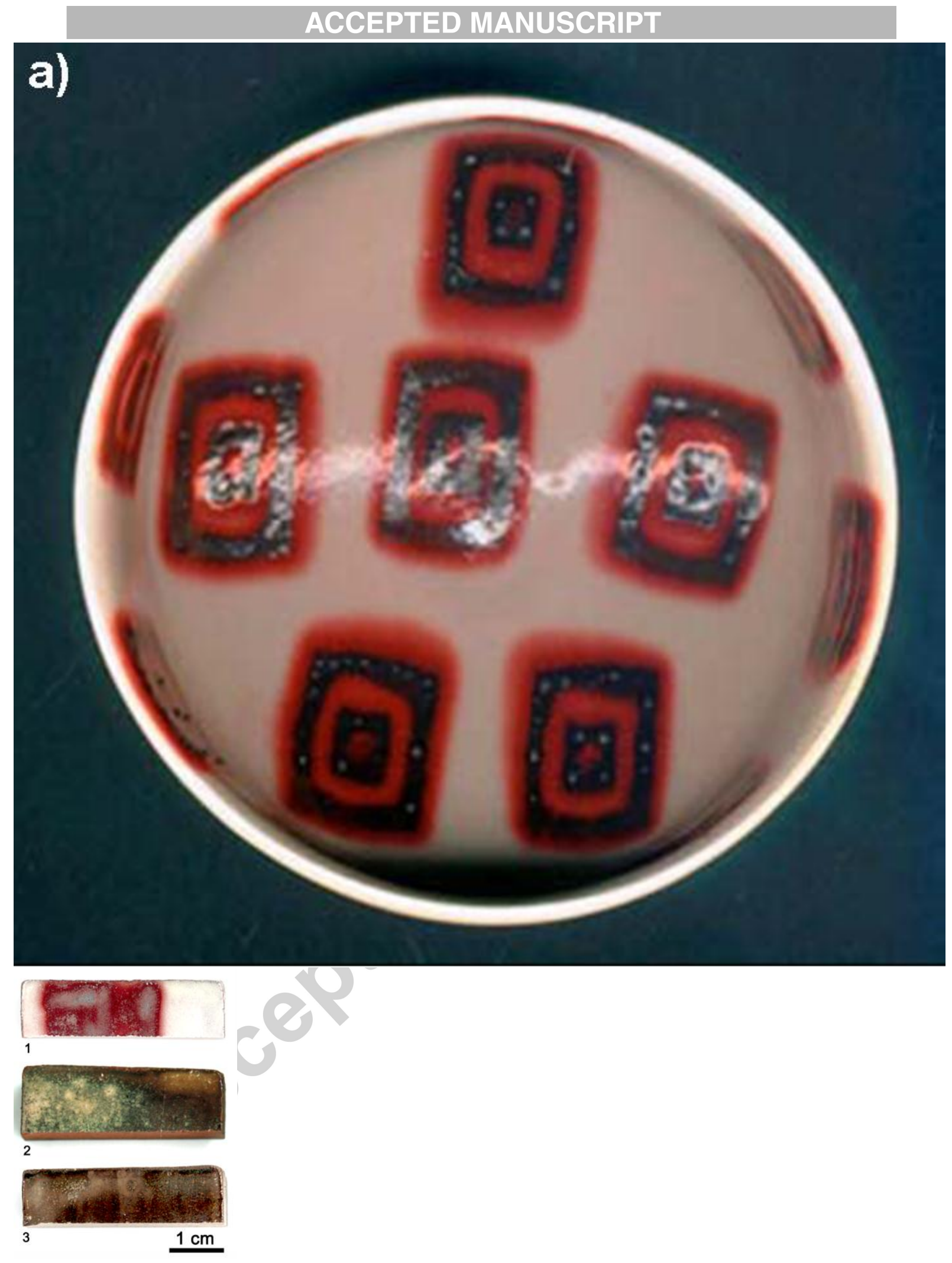



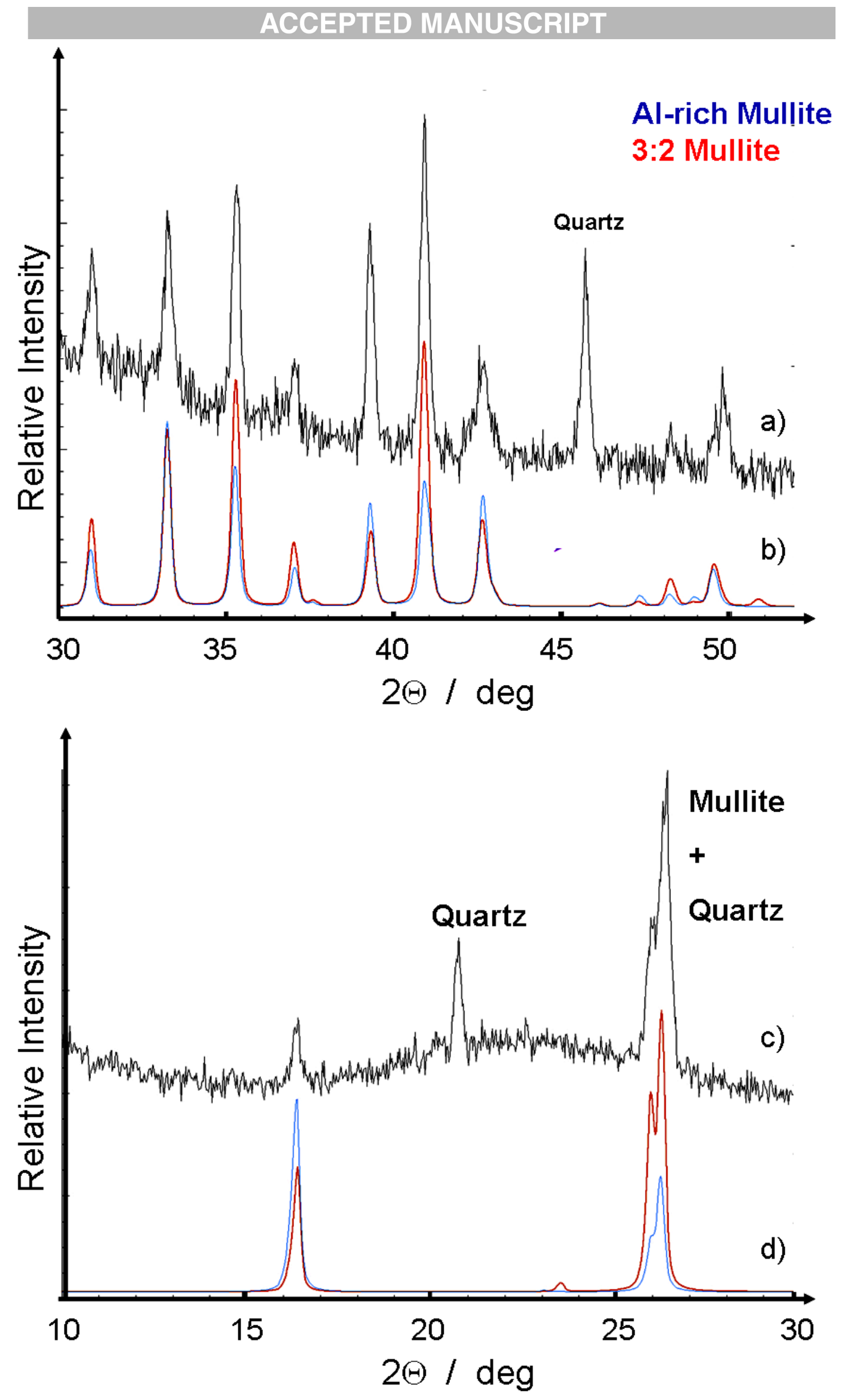


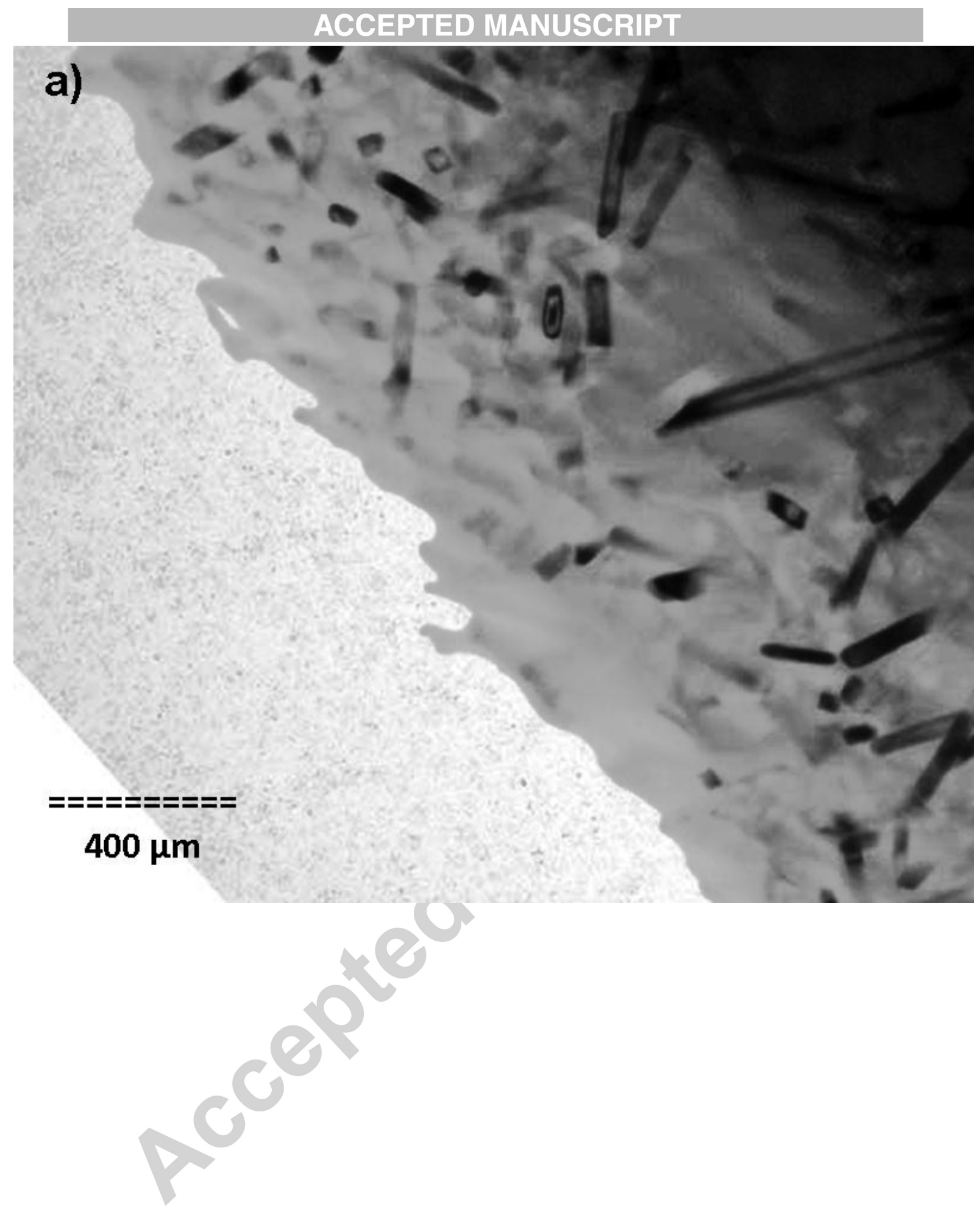




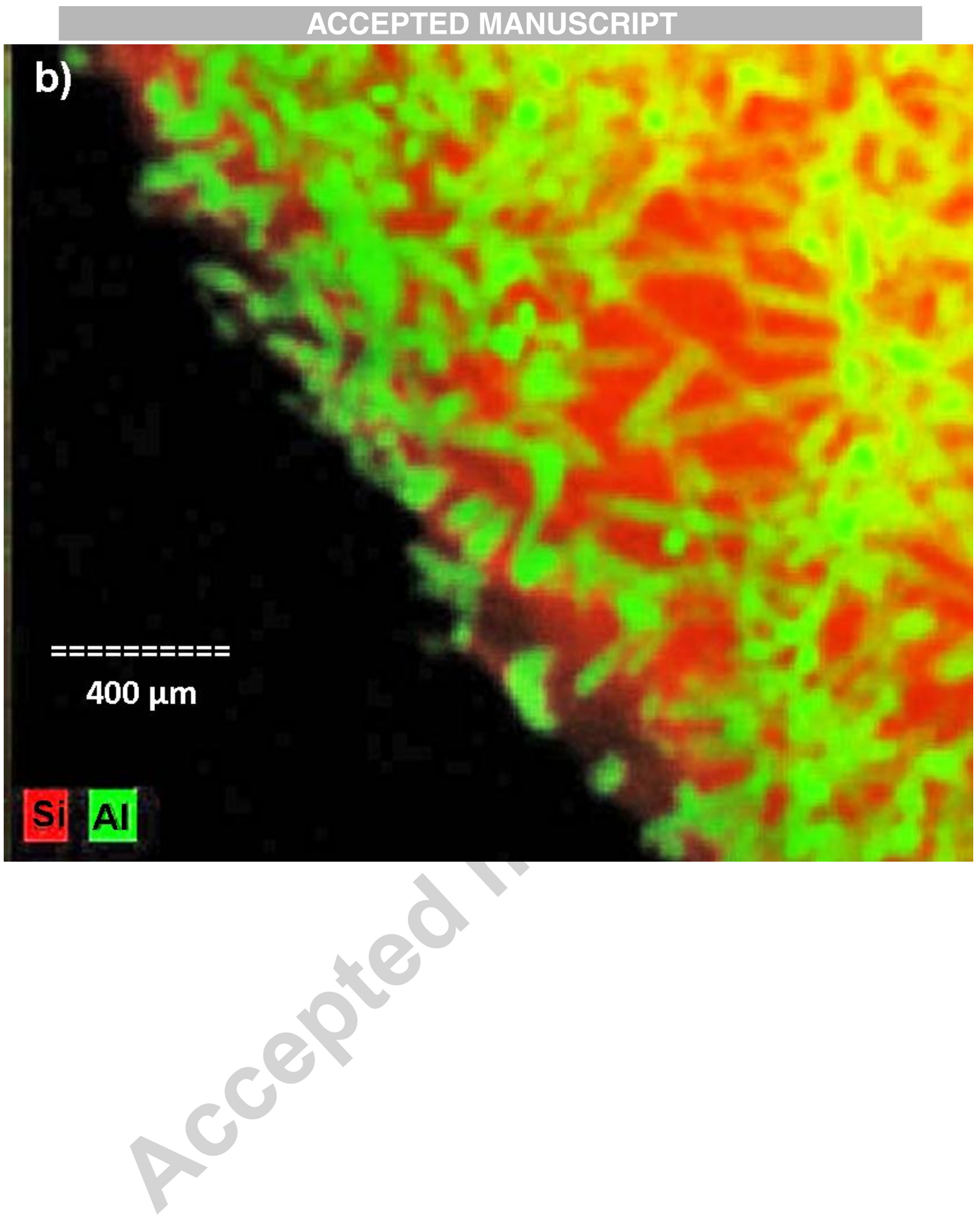




\section{ACCEPTED MANUSCRIPT}

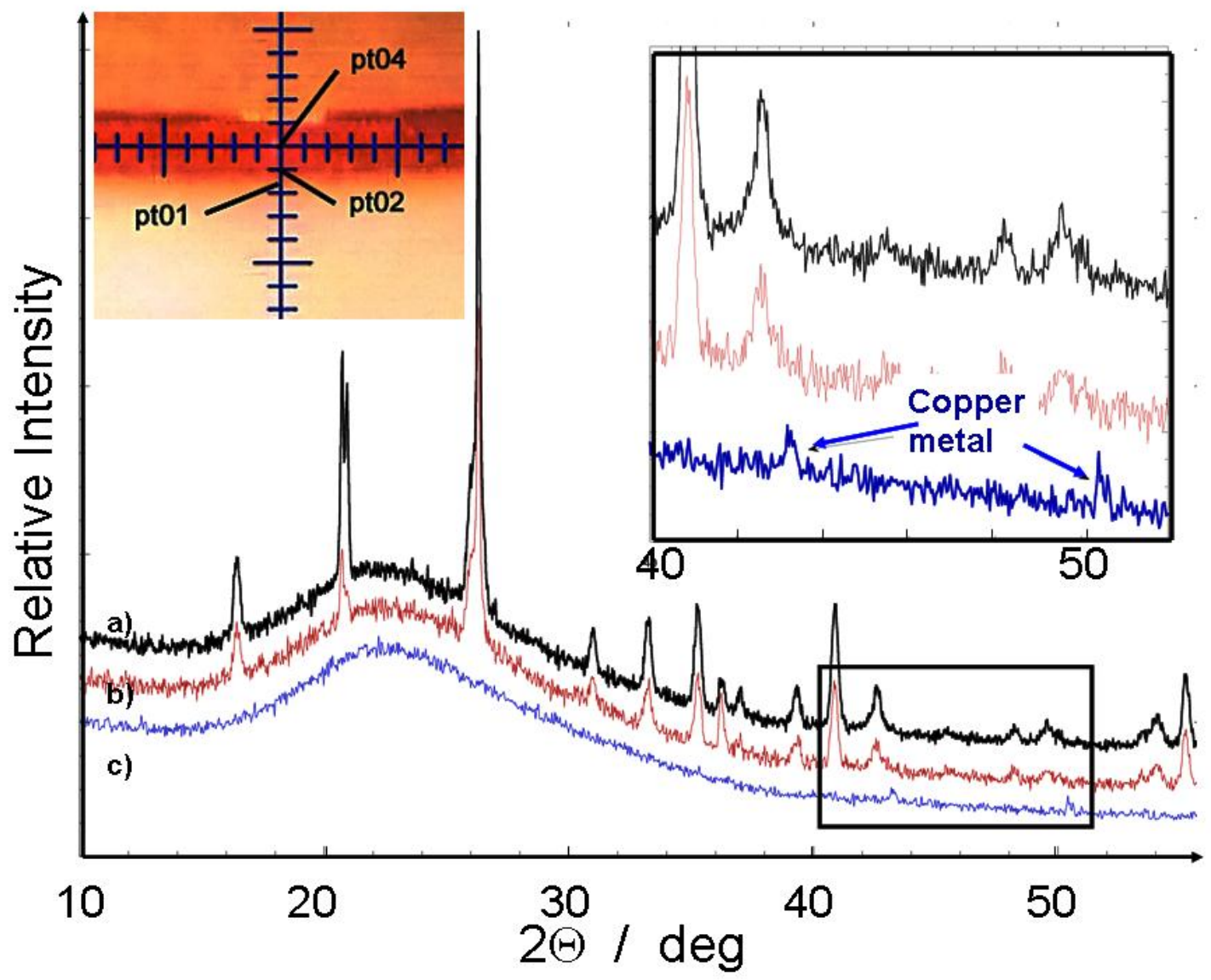

\section{a)}

$200 \mu \mathrm{m}$

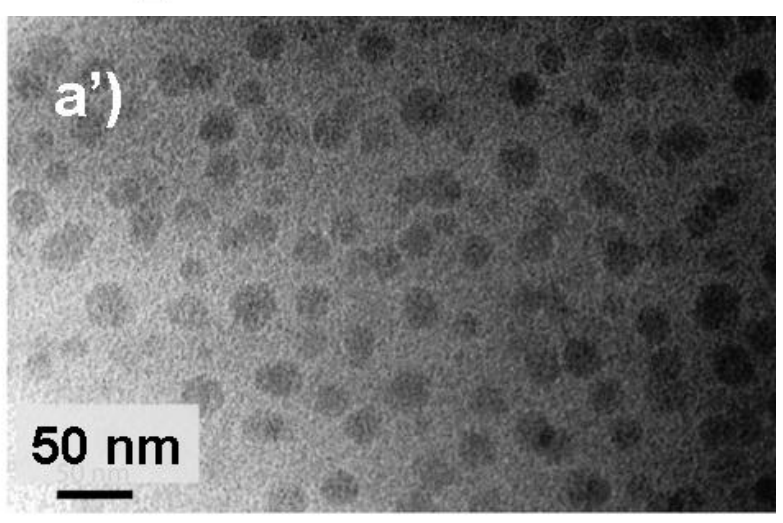

b)

c)
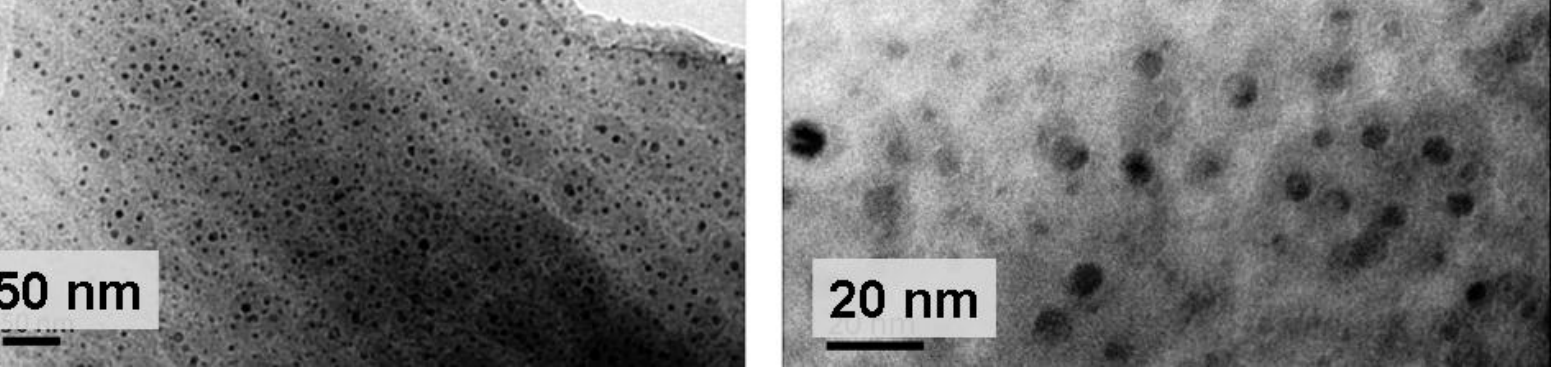

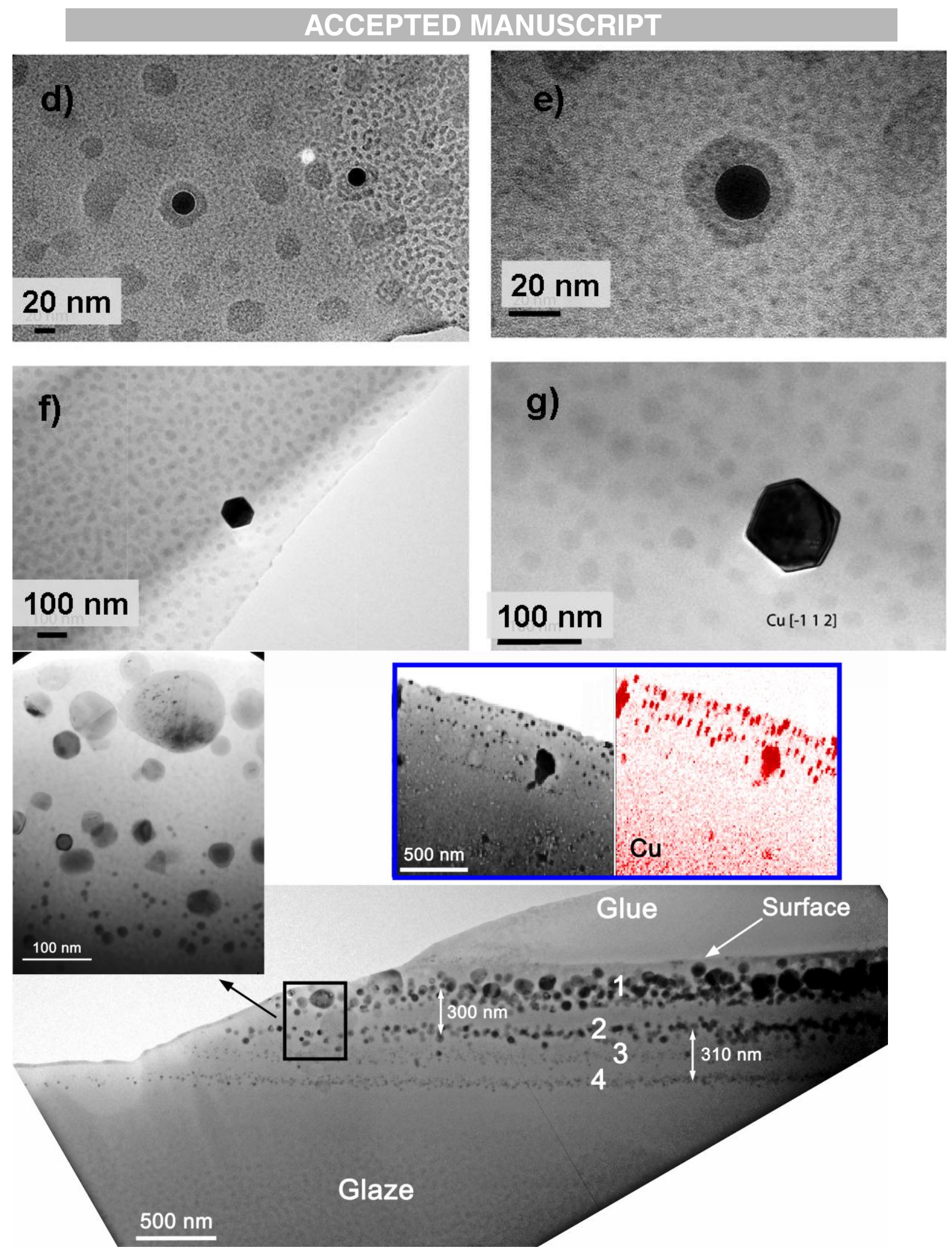


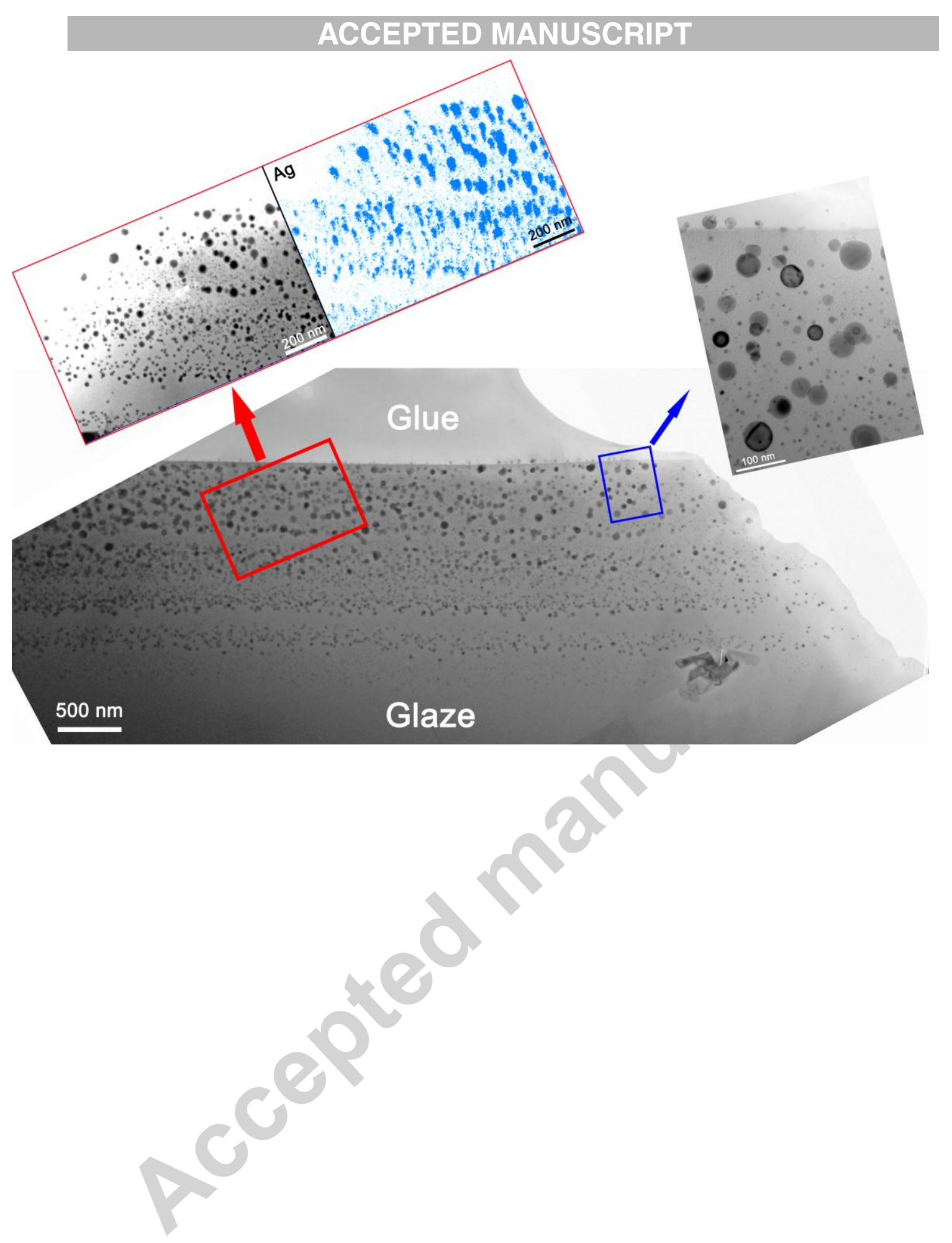

